\title{
Parasitic infections of the spine: case series and review of the literature
}

\author{
Neil Majmundar, MD, Purvee D. Patel, MD, Vincent Dodson, BS, Ashley Tran, BS, \\ Ira Goldstein, MD, and Rachid Assina, MD \\ Department of Neurosurgery, Rutgers New Jersey Medical School, Newark, New Jersey
}

OBJECTIVE Although parasitic infections are endemic to parts of the developing world and are more common in areas with developing economies and poor sanitary conditions, rare cases may occur in developed regions of the world.

METHODS Articles eligible for the authors' literature review were initially searched using PubMed with the phrases "parasitic infections" and "spine." After the authors developed a list of parasites associated with spinal cord infections from the initial search, they expanded it to include individual diagnoses, using search terms including "neurocysticercosis," "schistosomiasis," "echinococcosis," and "toxoplasmosis."

RESULTS Two recent cases of parasitic spinal infections from the authors' institution are included.

CONCLUSIONS Key findings on imaging modalities, laboratory studies suggestive of parasitic infection, and most importantly a thorough patient history are required to correctly diagnose parasitic spinal infections.

https://thejns.org/doi/abs/10.3171/2018.10.FOCUS18472

KEYWORDS parasite; spinal infection; neurocysticercosis; schistosomiasis; echinococcosis; toxoplasmosis

A LTHOUGH parasitic infections are more common worldwide in areas with developing economies and poor sanitary conditions, rare cases may occur in developed regions of the world. There are a number of rare parasitic diseases that may involve the CNS, causing patients to present with common symptoms such as seizures, motor or sensory deficits, and pain. It is imperative that clinicians develop a broad differential diagnosis when evaluating these patients, even when clinical symptoms and workup may direct one toward an inflammatory, neoplastic, or degenerative process. Patient history and demographics are vital to the diagnosis of these diseases.

A number of these parasitic diseases affecting the CNS may involve the spine. Patients may present with typical symptoms such as back pain, numbness, weakness, or bowel/bladder incontinence, leading the clinician to order relevant imaging of the CNS. In cases of parasitic infection, there is seldom a diagnosis made even after imaging identifies the underlying lesion. These lesions can easily be mistaken for other more common surgically treatable pathologies. Therefore, thorough understanding of the presentation and guidelines for treatment of these rare parasitic infections is necessary, especially as the population of the US diversifies and parasitic infections are identified more often. In this case discussion and review of the literature, we present the most common parasitic spinal infections, their clinical presentation, risk factors, and the most up-to-date management guidelines.

\section{Methods}

We reviewed 2 unique cases of parasitic spinal infections at our institution and the relevant imaging. Articles eligible for our literature review were initially searched using PubMed with the phrases "parasitic infections" and "spine." After we developed a list of parasites associated with spinal cord infections from our initial search, we expanded it to include individual diagnoses, using search terms including "neurocysticercosis," "schistosomiasis," "echinococcosis," and "toxoplasmosis." All articles within 
TABLE 1. General characteristics of spinal parasitic infections

\begin{tabular}{|c|c|c|c|c|c|c|}
\hline $\begin{array}{l}\text { Name of } \\
\text { Disease }\end{array}$ & Pathogen & Transmission & Signs \& Symptoms & Imaging & Diagnosis & Treatment \\
\hline $\begin{array}{l}\text { Neurocysti- } \\
\text { cercosis }\end{array}$ & T. solium & $\begin{array}{l}\text { Ingestion of } T \text {. solium } \\
\quad \text { eggs }^{17}\end{array}$ & $\begin{array}{l}\text { Brain cysts (4 stages): } \\
\text { vesicular, colloidal, } \\
\text { nodular/granular, \& } \\
\text { calcified granulo- } \\
\text { mas; }{ }^{13} \text { seizures/ep- } \\
\text { ilepsy; headaches; } \\
\text { focal neurological } \\
\text { deficits }^{17}\end{array}$ & $\begin{array}{l}\text { 1) Vesicular stage: well-defined } \\
\text { scolex:13,17 } 2 \text { 2) colloidal stage: } \\
\text { ring enhancement, loss of } \\
\text { scolex, edema; }{ }^{: 13,17} \text { 3) nodular/ } \\
\text { granular stage: decreased } \\
\text { enhancement \& edema, initia- } \\
\text { tion of calcification, no cystic } \\
\text { component; }{ }^{13,17} 4 \text { ) calcified } \\
\text { stage: calcified lesions }{ }^{60}\end{array}$ & $\begin{array}{l}\text { Epidemiologi- } \\
\text { cal factors, } \\
\text { neuroimag- } \\
\text { ing, sero- } \\
\text { logical tests, } \\
\text { fundoscopy, } \\
\text { histology15,17 }\end{array}$ & $\begin{array}{l}\text { Antiparasitic thera- } \\
\text { py (albendazole, } \\
\text { praziquantel) \& } \\
\text { corticosteroids } \\
\text { (not recom- } \\
\text { mended in pa- } \\
\text { tients w/ calci- } \\
\text { fied lesions);24,58 } \\
\text { antiepileptics }\end{array}$ \\
\hline $\begin{array}{l}\text { Schistoso- } \\
\text { miasis }\end{array}$ & $\begin{array}{l}\text { S. mansoni, } \\
\text { S. haema- } \\
\text { tobium, S. } \\
\text { japonicum }\end{array}$ & $\begin{array}{l}\text { Penetration of skin by } \\
\text { schistosomal larvae }^{17}\end{array}$ & $\begin{array}{l}\text { Muscle weakness, } \\
\text { asymmetrical } \\
\text { sensorimotor ab- } \\
\text { normalities, altered } \\
\text { mental status, } \\
\text { high eosinophil } \\
\text { count, lumbar pain, } \\
\text { radiculopathy } \\
\text { ra,23 }\end{array}$ & $\begin{array}{l}\text { MRI_abnormal T1WI \& T2WI } \\
\text { signals, heterogeneous pat- } \\
\text { tern of enhancement, spinal } \\
\text { cord compression, enlarged } \\
\text { spinal cord } \\
\text { 17,49 }\end{array}$ & $\begin{array}{l}\text { Kato-Katz } \\
\text { thick-smear, } \\
\text { ELISA, IHA, } \\
\text { or immuno- } \\
\text { fluorescence, } \\
\text { neuroimag- } \\
\text { ing }{ }^{48}\end{array}$ & $\begin{array}{l}\text { Praziquantel \& } \\
\text { corticosteroids, } \\
\text { artemether } \\
\text { (prophylaxis) }^{48}\end{array}$ \\
\hline $\begin{array}{l}\text { Echinococ- } \\
\text { cosis }\end{array}$ & $\begin{array}{l}\text { E. granulo- } \\
\text { sus }\end{array}$ & $\begin{array}{l}\text { Ingestion of Echinococ- } \\
\text { cus eggs }{ }^{17}\end{array}$ & $\begin{array}{l}\text { Long history of back } \\
\text { pain, neurological } \\
\text { deficits, spinal } \\
\text { compression } \\
\text { syndrome }{ }^{28,45}\end{array}$ & $\begin{array}{l}\text { Well-defined multiloculated } \\
\text { osteolytic lesion; }{ }^{59} \mathrm{~T} 2 \mathrm{Wl} \\
\text { showing cystic lesions w/ high } \\
\text { signal intensity; hypointense } \\
\text { lesions on T1W|59 }\end{array}$ & $\begin{array}{l}\text { Neurological } \\
\text { examination, } \\
\text { neuroimag- } \\
\text { ing, serologi- } \\
\text { cal tests } \\
\text { 17,28 }\end{array}$ & $\begin{array}{l}\text { Surgery w/ con- } \\
\text { comitant anti- } \\
\text { parasitic therapy } \\
\text { (albendazole, } \\
\text { mebendazole) }{ }^{40}\end{array}$ \\
\hline $\begin{array}{l}\text { Toxoplas- } \\
\text { mosis }\end{array}$ & T. gondii & $\begin{array}{l}\text { Ingestion of cysts in un- } \\
\text { dercooked meat or of } \\
\text { oocysts in contami- } \\
\text { nated food \& water; } \\
\text { spinal toxoplasmosis } \\
\text { typically only seen in } \\
\text { immunocompromised } \\
\text { patients }^{31}\end{array}$ & $\begin{array}{l}\text { Acute-onset parapa- } \\
\text { resis, sensory \& } \\
\text { bladder dysfunc- } \\
\text { tion, fever }{ }^{3,26}\end{array}$ & $\begin{array}{l}\text { Enhanced intramedullary le- } \\
\quad \text { sions }^{47}\end{array}$ & $\begin{array}{l}\text { Serum \& CSF } \\
\text { cytology \& } \\
\text { immunologi- } \\
\text { cal studies, } \\
\text { neuroimag- } \\
\text { ing }\end{array}$ & $\begin{array}{l}\text { Oral pyrimeth- } \\
\text { amine \& sulfa- } \\
\text { diazine, steroids } \\
\text { (requires further } \\
\text { investigation) }{ }^{26,47}\end{array}$ \\
\hline
\end{tabular}

$\mathrm{T} 1 \mathrm{WI}=\mathrm{T} 1$-weighted imaging; $\mathrm{T} 2 \mathrm{WI}=\mathrm{T}$ - -weighted imaging .

these searches were screened, and we included articles focusing on the parasitic infections specifically affecting the spinal cord and spine. The majority of the studies were case reports (Tables 1-5).

\section{Case Reports \\ Case 1}

This patient was a 49-year-old man with a past medical history of tuberculosis who presented to our institution with the chief complaint of sensory loss in his arms and legs. The patient was originally from Guatemala and had resided in the US for approximately 3 years. On initial neurological examination, he had decreased sensation to light touch in the upper extremities, worse on the right side. His motor function was preserved. He was also found to have marked impairment in proprioception. MRI sequences of the cervical spine demonstrated large, cystic, enhancing lesions, most prominent dorsal to the spinal cord and causing significant compression. The most prominent lesion spanned the posterior fossa through $\mathrm{C} 2$, and an additional lesion was causing stenosis at C6-7. Additional imaging demonstrated multiple enhancing lesions as well as calcified nodules throughout the brain. MRI of the thoracic and lumbar spine demonstrated diffuse meningeal enhancement as well as several more enhancing lesions. The patient was started on albendazole as well as steroids.

Due to his neurological deficit, the patient underwent a suboccipital craniectomy and $\mathrm{C} 1$ laminectomy for resection of the intradural extramedullary lesions. Multiple large intradural cysts were encountered and removed. Both imaging and pathology were consistent with neurocysticercosis (Figs. 1 and 2). Postoperatively, the patient did well and continued to demonstrate improvement in his sensory deficits on follow-up. He was continued on albendazole and his steroids were tapered off.

\section{Case 2}

This patient was a 38-year-old man who had a 1-year history of low-back pain. He was known to have a pelvic mass of unknown origin, which was being monitored by his primary care provider. He presented to our institution with a 1-week history of bowel incontinence as well as subjective lower-extremity weakness. He denied urinary incontinence. On neurological examination, the patient 
TABLE 2. Case reports and larger case series of neurocysticercosis

\begin{tabular}{|c|c|c|c|c|c|c|}
\hline $\begin{array}{l}\text { Case } \\
\text { Reports }\end{array}$ & $\begin{array}{l}\text { Pt Age } \\
\text { (yrs), } \\
\text { Sex }\end{array}$ & Symptoms & Imaging & Biopsy Findings & Treatment & $\begin{array}{l}\text { Improvement } \\
\quad \text { of } \\
\text { Symptoms? }\end{array}$ \\
\hline $\begin{array}{r}\text { Sheehan et } \\
\text { al., } 2002\end{array}$ & $16, F$ & $\begin{array}{l}\text { Progressive bilat hand pares- } \\
\text { thesias, decreased respira- } \\
\text { tory rate }\end{array}$ & $\begin{array}{l}\text { MRI showed intraparenchymal lesion, } \\
\text { cystic in nature w/ rim enhancement, } \\
\text { at C1-2 w/ focal cord enlargement \& } \\
\text { signs of edematous change }\end{array}$ & $\begin{array}{l}\text { Cyst wall remnants } \\
\text { from intramedul- } \\
\text { lary cysticercosis, } \\
\text { reactive gliosis }\end{array}$ & $\begin{array}{l}\text { Resection, } \\
\text { praziqu- } \\
\text { antel, \& } \\
\text { steroids }\end{array}$ & Yes \\
\hline $\begin{array}{l}\text { Chaurasia } \\
\text { et al., } \\
2015\end{array}$ & $35, \mathrm{M}$ & $\begin{array}{l}\text { Back pain, unilat rt lower-ex- } \\
\text { tremity weakness, decreased } \\
\text { sensation to pain \& temp } \\
\text { on It, decreased sensation } \\
\text { to position \& vibration on rt } \\
\text { (clinical Brown-Séquard), uri- } \\
\text { nary retention, constipation }\end{array}$ & $\begin{array}{l}\text { MRI showed ring-shaped cysticercosis } \\
\text { lesion w/ eccentric dot (scolex of } \\
\text { larvae) at T11 }\end{array}$ & No biopsy & $\begin{array}{l}\text { Albendazole } \\
\text { \& pred- } \\
\text { nisolone }\end{array}$ & Yes \\
\hline $\begin{array}{l}\text { Torabi et al., } \\
2004\end{array}$ & $35, \mathrm{M}$ & $\begin{array}{l}\text { Low-back pain; progressive rt } \\
\text { leg weakness; decreased } \\
\text { sensation to light touch, } \\
\text { vibration, \& position in rt leg; } \\
\text { decreased sensation to temp } \\
\text { in It leg; urinary incontinence }\end{array}$ & $\begin{array}{l}\text { MRI showed abnormal intramedullary } \\
\text { enhancement on It C5 \& rt T4, w/ } \\
\text { abnormal signal in T5-9, conus } \\
\text { medullaris, \& thecal sac }\end{array}$ & No biopsy & $\begin{array}{l}\text { Albendazole } \\
\text { \& dexa- } \\
\text { methasone }\end{array}$ & Yes \\
\hline $\begin{array}{l}\text { Larger Case } \\
\quad \text { Series }\end{array}$ & $\begin{array}{l}\text { No. of } \\
\text { Pts }\end{array}$ & \multicolumn{5}{|c|}{ Significant Findings } \\
\hline $\begin{array}{l}\text { Colli et al., } \\
2002\end{array}$ & 12 & \multicolumn{5}{|c|}{$\begin{array}{l}\text { In } 9 \text { of } 12 \text { pts cysticercosis was associated w/ hydrocephalus, \& each of these pts developed nerve root compression symptoms } \\
7-48 \text { mos later. Prognosis was worse in pts w/ associated arachnoiditis \& spinal cord compression. }\end{array}$} \\
\hline $\begin{array}{l}\text { Alsina et al., } \\
2002\end{array}$ & 6 & \multicolumn{5}{|c|}{$\begin{array}{l}\text { Subarachnoid spinal neurocysticercosis occurred in } 5 \text { pts \& intramedullary neurocysticercosis occurred in } 1 \text { pt. All pts were even- } \\
\text { tually ambulatory after treatment. Only the pt w/ intramedullary neurocysticercosis was managed w/ medical therapy alone. }\end{array}$} \\
\hline $\begin{array}{l}\text { Del Brutto } \\
\quad \& \text { Garcia, } \\
2013\end{array}$ & 43 & \multicolumn{5}{|c|}{$\begin{array}{l}\text { All pts presented w/ some degree of transverse myelopathy. On MRI, the scolex of the parasite was only visualized in } 16 \text { pts. Of } \\
\text { the } 20 \text { pts treated w/ surgery, } 12 \text { fully recovered, whereas all } 13 \text { medically treated pts fully recovered. }\end{array}$} \\
\hline
\end{tabular}

$\mathrm{Pt}=$ patient; temp $=$ temperature.

had intact motor strength in the arms and legs and decreased sensation in the plantar aspect of the right foot. MRI sequences of the patient's lumbar spine demonstrated a complex-appearing polycystic mass extending from the pelvis through two of the sacral neural foramina into the epidural space from the L5-S1 junction down to the bottom of the sacrum. Severe mass effect and obliteration of the foraminal contents on the right side at S1-2 and S2-3 were demonstrated (Fig. 3).

The patient underwent bilateral L5 laminotomies and S1-2 laminectomies for resection of the epidural mass. According to pathological findings, the epidural mass was suggestive of parasitic infection, specifically Echinococcus. The patient was started on albendazole and corticosteroids for treatment, and his right lower-extremity paresthesias and sensation improved dramatically.

\section{Discussion Neurocysticercosis}

Cysticercosis, the most common parasitic infection of the CNS, is caused by Taenia solium. The disease occurs secondary to the ingestion of embryonated parasite eggs. Once ingested, the parasite traverses through the small bowel into the bloodstream to reach a variety of sites, including the skeletal muscles, eyes, and neural structures. This parasite affects approximately 50 million people worldwide and carries a prevalence of $3 \%-6 \% .{ }^{17}$ Although the parasite mainly affects endemic regions, it has become more prevalent in the US due to the immigration of patients from highly affected regions. ${ }^{16}$ Intracranial involvement is more common with this pathology; spinal cysticercosis has an incidence of only $1.5 \%-3 \%$.

Spinal neurocysticercosis involving the spinal cord is extremely uncommon-it is reported to be seen in only $1 \%-6 \%$ of patients diagnosed with neurocysticercosis. ${ }^{55}$ Leptomeningeal involvement is relatively more common; it is found approximately 6-8 times more often than the intramedullary form. ${ }^{17}$ The intramedullary form occurs secondary to hematogenous spread, whereas the intradural-extramedullary lesions are thought to be "drop lesions" that spread from the intracranial space. Similar to neoplastic lesions, neurocysticercosis lesions may be found in the vertebral bodies, in epidural/subdural/subarachnoid spaces, and within the spinal cord itself (intramedullary). Due to the mass effect and limited space within the canal relative to the intracranial space, spinal cysticercosis may be more likely to result in neurological compromise. Neurological deficits occur secondary to mass effect from the cysts as well as an inflammatory reaction following 
TABLE 3. Case reports and larger case series of neuroschistosomiasis

\begin{tabular}{|c|c|c|c|c|c|c|}
\hline $\begin{array}{c}\text { Case } \\
\text { Reports }\end{array}$ & $\begin{array}{l}\text { Pt Age } \\
\text { (yrs), } \\
\text { Sex }\end{array}$ & Symptoms & Imaging & Biopsy Findings & Treatment & $\begin{array}{l}\text { Improvement } \\
\text { of } \\
\text { Symptoms? }\end{array}$ \\
\hline $\begin{array}{l}\text { Ueki et al., } \\
\quad 1995\end{array}$ & $34, \mathrm{M}$ & $\begin{array}{l}\text { Urinary retention, low-back } \\
\text { pain, progressive spastic } \\
\text { paraparesis, decreased } \\
\text { sensation below T10 level }\end{array}$ & $\begin{array}{l}\text { MRI showed enlarged } \\
\text { spinal cord below T9 w/ } \\
\text { spotty enhancement }\end{array}$ & $\begin{array}{l}\text { S. mansoni ova w/ granulo- } \\
\text { matous inflammation }\end{array}$ & $\begin{array}{l}\text { Resection, praziquan- } \\
\text { tel, \& dexametha- } \\
\text { sone }\end{array}$ & Yes \\
\hline $\begin{array}{l}\text { Palin et al., } \\
\quad 2015\end{array}$ & $20, F$ & $\begin{array}{l}\text { Progressive low-back pain } \\
\text { radiating to both legs, } \\
\text { lower leg weakness, } \\
\text { urinary retention }\end{array}$ & $\begin{array}{l}\text { MRI showed an edema- } \\
\text { tous, expanded conus } \\
\text { w/ enhancement from } \\
\text { T10-11 to L1-2 }\end{array}$ & $\begin{array}{l}\text { Chronic granulomatous } \\
\text { inflammation w/ positive } \\
\text { Schistosoma serology }\end{array}$ & $\begin{array}{l}\text { Resection, praziquan- } \\
\text { tel, \& methylpred- } \\
\text { nisolone, followed } \\
\text { by prednisone }\end{array}$ & Yes \\
\hline $\begin{array}{l}\text { Odeku et al., } \\
1968\end{array}$ & $13, \mathrm{M}$ & $\begin{array}{l}\text { Progressive low-back pain, } \\
\text { bilat leg weakness, } \\
\text { urinary hesitancy }\end{array}$ & & $\begin{array}{l}\text { Schistosomal granuloma w/ } \\
\text { S. hematobium ova }\end{array}$ & $\begin{array}{l}\text { Resection, niridazole, } \\
\text { promethazine, high } \\
\text { fluid intake }\end{array}$ & Yes \\
\hline $\begin{array}{l}\text { Kamel et al., } \\
2005\end{array}$ & $62, \mathrm{M}$ & $\begin{array}{l}\text { Progressing lower-extremity } \\
\text { myelopathy }\end{array}$ & $\begin{array}{l}\text { MRI showed diffuse patchy } \\
\text { signal change in lower } \\
\text { thoracic cord associated } \\
\text { w/ spinal cord swelling }\end{array}$ & $\begin{array}{l}\text { No biopsy; serum schis- } \\
\text { tosomal ELISA was } \\
\text { positive }\end{array}$ & $\begin{array}{l}\text { Praziquantel \& } \\
\text { steroids }\end{array}$ & Yes \\
\hline $\begin{array}{l}\text { Herskowitz, } \\
1972\end{array}$ & $29, \mathrm{M}$ & $\begin{array}{l}\text { Back pain, leg weakness, } \\
\text { difficulty in urination, } \\
\text { constipation }\end{array}$ & & $\begin{array}{l}\text { Focal areas of necrosis w/ } \\
\text { granulomatous reaction } \\
\text { enclosing S. mansoni ova }\end{array}$ & $\begin{array}{l}\text { Resection, fuadin, \& } \\
\text { Decadron }\end{array}$ & Yes \\
\hline $\begin{array}{l}\text { Larger Case } \\
\text { Series }\end{array}$ & $\begin{array}{l}\text { No. of } \\
\text { Pts }\end{array}$ & \multicolumn{5}{|c|}{ Significant Findings } \\
\hline $\begin{array}{l}\text { Ferrari et al., } \\
\qquad 2011^{22}\end{array}$ & 4 & \multicolumn{5}{|c|}{$\begin{array}{l}\text { Immune complexes containing soluble egg antigen of } S \text {. mansoni were found in the CSF of } 4 \mathrm{pts} w / \text { spinal cord schistosomia- } \\
\text { sis, suggesting an inflammatory disease process. }\end{array}$} \\
\hline $\begin{array}{l}\text { Wan et al., } \\
2006\end{array}$ & 10 & \multicolumn{5}{|c|}{$\begin{array}{l}10 \text { adult pts from a Schistosoma-endemic area presented w/ progressive lower-extremity weakness, along w/ bowel \& bladder } \\
\text { dysfunction, \& lesions were misdiagnosed as tumor. Pathology later revealed conus medullaris schistosomiasis, a form of } \\
\text { ectopic schistosomiasis. Serological testing was positive for Schistosoma lgG in all cases. }\end{array}$} \\
\hline $\begin{array}{l}\text { Silva et al., } \\
\quad 2004\end{array}$ & 16 & \multicolumn{5}{|c|}{$\begin{array}{l}16 \text { adult pts from a Schistosoma-endemic area w/ known schistosomal myeloradiculopathy w/ symptoms including lower-ex- } \\
\text { tremity weakness/anesthesia/pain, bladder incontinence, \&/or sexual impotence were treated w/ praziquantel, methylpred- } \\
\text { nisolone, \& prednisone, \& were shown to have significant improvement of neurological symptoms. }\end{array}$} \\
\hline $\begin{array}{l}\text { Jiang et al., } \\
2008\end{array}$ & 4 & \multicolumn{5}{|c|}{$\begin{array}{l}4 \text { pts w/ acute progression of motor, sensory, \& autonomic dysfunctions were found to have spinal cord schistosomiasis } \\
\text { secondary to S. japonicum (less frequent). CSF samples from all pts were ELISA positive for S. japonicum. Resection \& } \\
\text { administration of praziquantel \& steroids were both required for adequate treatment. All pts had improvement of symptoms. }\end{array}$} \\
\hline
\end{tabular}

treatment. In addition, patients may present with a variety of symptoms ranging from expected clinical findings concordant with lesion location to those that are less common, such as Brown-Séquard syndrome. ${ }^{10}$

Neurocysticercosis typically occurs in 4 stages. The vesicular stage is first, with the presence of a cyst and scolex. The next stage (colloidal) demonstrates ring enhancement and edema. In the third stage (nodular-granular) there is decreased enhancement and edema. During the nodulargranular stage calcification of the lesions begins. The fourth and final stage is called the calcified stage, and it is during this stage that CT/MRI sequences will demonstrate calcification. ${ }^{17}$ The best imaging modality is MRI with gadolinium because it will demonstrate mass effect, edema, and enhancement as well as the intensity of the cystic fluid. In addition, high-resolution T2-weighted sequences (3D constructive interference in steady state [3DCISS]) can demonstrate the cyst and scolex. Subarachnoid cysts can be delineated using MR myelography. In cases of intramedullary involvement, it is extremely difficult to differentiate neurocysticercosis from other vascular, inflammatory, demyelinating, or neoplastic pathologies without additional information, such as the presence of other lesions in the intracranial space.

Treatment for patients who are asymptomatic typically involves an antiparasitic agent, usually albendazole, combined with an antiinflammatory medication, typically corticosteroids, to reduce inflammation due to larval death. ${ }^{24}$ Surgical intervention is reserved for patients presenting with mass lesions causing neurological deficits. Spinal lesions such as intramedullary lesions are rarely an indication for surgery. Only those lesions that are accessible by using a low-morbidity approach should undergo resection.

\section{Neuroschistosomiasis}

Schistosomiasis is an infection caused by blood-dwelling platyhelminths (flatworms) from the genus Schistosoma, which affects more than 230 million people in 74 countries across Africa, Asia, and the Americas., ${ }^{952}$ Incidence of this disease is generally found in endemic areas, 
TABLE 4. Case reports of toxoplasmosis

\begin{tabular}{|c|c|c|c|c|c|c|}
\hline $\begin{array}{l}\text { Case } \\
\text { Reports }\end{array}$ & $\begin{array}{l}\text { Pt } \\
\text { Age } \\
\text { (yrs), } \\
\text { Sex }\end{array}$ & Symptoms & Imaging & Biopsy Findings & Treatment & $\begin{array}{l}\text { Improvement } \\
\quad \text { of } \\
\text { Symptoms? }\end{array}$ \\
\hline $\begin{array}{l}\text { Resnick et } \\
\text { al., } 1995\end{array}$ & $45, M$ & $\begin{array}{l}\text { Lower-extremity weak- } \\
\text { ness \& coordination } \\
\text { difficulty, urinary } \\
\text { retention }\end{array}$ & $\begin{array}{l}\text { MRI of spine showed long, } \\
\text { homogeneously enhancing } \\
\text { intramedullary lesion at T4, w/ } \\
\text { surrounding edema }\end{array}$ & $\begin{array}{l}\text { Profuse acute \& } \\
\text { chronic inflamma- } \\
\text { tion, Toxoplasma } \\
\text { tachyzoites }\end{array}$ & $\begin{array}{l}\text { Anti-Toxoplasma che- } \\
\text { motherapy }\end{array}$ & No \\
\hline $\begin{array}{l}\text { Garcia- } \\
\text { Gubern et } \\
\text { al., } 2010\end{array}$ & $40, M$ & $\begin{array}{l}\text { Flaccid paralysis of both } \\
\text { legs \& decreased sen- } \\
\text { sation to pain, touch, } \\
\text { temp, proprioception, \& } \\
\text { vibration }\end{array}$ & $\begin{array}{l}\text { Spinal MRI showed diffuse abnor- } \\
\text { mal hyperintense swelling; brain } \\
\text { MRI showed multiple bilat ring- } \\
\text { enhancing intraaxial lesions }\end{array}$ & $\begin{array}{l}\text { No biopsy; anti- } \\
\text { Toxoplasma lgG } \\
\text { immune titer was } \\
\text { positive, positive } \\
\text { for HIV }\end{array}$ & $\begin{array}{l}\text { Sulfadiazine, pyrimeth- } \\
\text { amine, folinic acid, } \\
\text { HAART for HIV, } \\
\text { dexamethasone, \& } \\
\text { methylprednisolone }\end{array}$ & Yes \\
\hline $\begin{array}{l}\text { García- } \\
\text { García et } \\
\text { al., } 2015\end{array}$ & $48, M$ & $\begin{array}{l}\text { Dysarthria, urinary reten- } \\
\text { tion, rt arm weakness, } \\
\text { decreased sensation to } \\
\text { temp \& pain }\end{array}$ & $\begin{array}{l}\text { T2 MRI of the spine showed diffuse } \\
\text { high signal from C4 to T10, w/ } \\
\text { enlargement at cervical level; } \\
\text { T1 MRI showed a fusiform intra- } \\
\text { medullary enhancing lesion btwn } \\
\text { C5 \& C6; brain MRI showed bilat } \\
\text { ring-enhancing lesions }\end{array}$ & Positive for HIV & $\begin{array}{l}\text { Antituberculosis } \\
\text { drugs, sulfadiazine, } \\
\text { pyrimethamine, \& } \\
\text { dexamethasone }\end{array}$ & Yes \\
\hline $\begin{array}{l}\text { Kung et al., } \\
\quad 2011\end{array}$ & $34, \mathrm{M}$ & $\begin{array}{l}\text { Bilat lower-extremity } \\
\text { weakness, sensory } \\
\text { level at L4, constipation }\end{array}$ & $\begin{array}{l}\text { Expansile intramedullary enhanc- } \\
\text { ing lesion at T11-12 }\end{array}$ & T. gondii cysts & $\begin{array}{c}\text { Resection, sulfadiazine, } \\
\text { pyrimethamine, dexa- } \\
\text { methasone, HAART }\end{array}$ & Yes \\
\hline $\begin{array}{l}\text { Rodríguez et } \\
\text { al., } 2013\end{array}$ & $40, M$ & Lumbar back pain & $\begin{array}{l}\text { Expansile medullary enhancing } \\
\text { lesion at } \mathrm{T} 10-12\end{array}$ & T. gondii tachyzoites & $\begin{array}{l}\text { TMP-SMX, clindamycin, } \\
\text { steroids (unspecified) }\end{array}$ & Yes \\
\hline
\end{tabular}

HAART = highly active antiretroviral therapy; TMP-SMX = trimethoprim-sulfamethoxazole.

but it has also been reported in Western countries due to immigration and tourism. Approximately 20 million people progress to develop severe disease, including infection within the CNS. ${ }^{17}$

There are 3 main organisms that are known to infect humans-Schistosoma japonicum, S. mansoni, and S. hematobium. Spinal cord lesions are often caused by infection from $S$. mansoni and S. hematobium, whereas $S$. japonica is responsible for most cases of cerebral schistosomiasis. ${ }^{52}$ There have, however, been some cases of $S$. japonica also leading to spinal infections. ${ }^{33}$

Initial transmission of these trematodes is from freshwater snails, which act as intermediate hosts and release infective cercaria into the water, which can then penetrate through human skin. Once inside the body, the cercaria transform into schistosomulum and migrate to the lungs via the lymphatic system and blood circulation; there they mature and then enter into portal circulation to carry out the remainder of their life cycle. ${ }^{9}$ Infection of the CNS is believed to be by either distribution of ova through venous shunts or retrograde migration of adult worms from the abdominal veins to the Batson venous plexus. ${ }^{9,17,52}$ The worms and ova travel through the valveless Batson plexus and into the venous system of the spinal cord. When ova are deposited within the spinal cord, there is an inflammatory response from the host, which leads to many of the neurological symptoms associated with this advanced stage of schistosomiasis. In more severe cases, inflammatory processes can lead to space-occupying granulomatous masses and necrosis of CNS tissue. Ferrari et al. found $S$. mansoni antigen-containing immune complexes within the CSF in all 4 of their patients with known spinal neuroschistosomiasis. 22

Clinically, spinal schistosomiasis tends to present acutely or subacutely and most often involves the lower spinal cord. ${ }^{23}$ One of the earliest signs can be low-back pain with radiation down to the lower extremities. Additional associated symptoms include lower-extremity weakness and paresthesias, bladder dysfunction, deep tendon reflex abnormalities, constipation, and sexual impotence.

The disease can present as acute myelopathy, conus medullaris syndrome, or acute/subacute lower-limb myeloradiculopathy. ${ }^{9}$ The medullary form, which involves the spinal cord predominantly, usually has a fast course and leads to severe weakness and a symmetrical distribution of symptoms. ${ }^{23}$ Conus medullaris syndrome develops over a slower course, has less severe symptoms, and is often asymmetrical in distribution. The myeloradiculopathy form is the most common presentation.

MRI is the imaging modality of choice to help diagnose spinal cord schistosomiasis. A common finding that can be seen is enlargement of the spinal cord, specifically in the lower spinal cord and conus medullaris region. ${ }^{23,43}$, $50,53,56$ This is due to intramedullary granuloma formation. Saleem et al. noted moderate expansion of distal spinal cord in all 8 of their patients presenting with spinal cord schistosomiasis. ${ }^{50}$ Silva and colleagues reported this finding in $62.5 \%$ of patients. ${ }^{53}$ Another common finding is thickened cauda equina roots with heterogeneous contrast enhancement. ${ }^{2,23}$ 
TABLE 5. Case reports and larger case series of spinal hydatid disease

\begin{tabular}{|c|c|c|c|c|c|c|}
\hline $\begin{array}{l}\text { Case } \\
\text { Reports }\end{array}$ & $\begin{array}{l}\text { Pt Age } \\
\text { (yrs), } \\
\text { Sex }\end{array}$ & Symptoms & Imaging & Biopsy Findings & Treatment & $\begin{array}{l}\text { Improvement } \\
\quad \text { of } \\
\text { Symptoms? }\end{array}$ \\
\hline $\begin{array}{l}\text { Ashraf et al., } \\
2013\end{array}$ & $65, M$ & $\begin{array}{l}\text { Lumbar back pain, incon- } \\
\text { tinence, decreased } \\
\text { sensation bilaterally in } \\
\text { saddle distribution }\end{array}$ & $\begin{array}{l}\text { Multiple loculated cystic } \\
\text { swellings in It paraspi- } \\
\text { nal area at S2 }\end{array}$ & No biopsy & $\begin{array}{l}\text { Preop albendazole, excision, } \\
\text { postop albendazole \& pra- } \\
\text { ziquantel }\end{array}$ & Yes \\
\hline $\begin{array}{l}\text { Kaen et al., } \\
2009\end{array}$ & $59, \mathrm{M}$ & $\begin{array}{l}\text { Thoracic back pain, } \\
\text { bilat lower-extremity } \\
\text { weakness, numbness } \\
\text { below T6 }\end{array}$ & $\begin{array}{l}\text { MRI detected clusters of } \\
\text { multiloculated cysts } \\
\text { at T6 \& at T10-12 }\end{array}$ & No biopsy & $\begin{array}{l}\text { Excision, postop albendazole, } \\
\text { reop for recurrence of symp- } \\
\text { toms }\end{array}$ & No \\
\hline $\begin{array}{l}\text { Kotil et al., } \\
2010\end{array}$ & $30, F$ & $\begin{array}{l}\text { Lumbar back pain, rt } \\
\text { sciatic pain, difficulty } \\
\text { ambulating }\end{array}$ & $\begin{array}{l}\text { T1 MRI demonstrated } \\
\text { hypointense cystic } \\
\text { lesion in L4-5 region; } \\
\text { T2 MRI demonstrated } \\
\text { hyperintense lesion }\end{array}$ & No biopsy & Albendazole & Yes \\
\hline $\begin{array}{l}\text { El-On et al., } \\
2003\end{array}$ & $53, \mathrm{M}$ & $\begin{array}{l}\text { Back pain, difficulty } \\
\text { ambulating }\end{array}$ & $\begin{array}{l}\text { MRI demonstrated } \\
\text { destruction of L4 \& } \\
\text { cystic lesions in rt } \\
\text { iliopsoas muscle }\end{array}$ & $\begin{array}{l}\text { Protoscolices demon- } \\
\text { strated microscopi- } \\
\text { cally from sample } \\
\text { acquired from CT- } \\
\text { guided aspiration }\end{array}$ & $\begin{array}{l}\text { Preop albendazole, excision, } \\
\text { continued albendazole postop, } \\
\text { repeat surgery after neurologi- } \\
\text { cal deterioration, combination } \\
\text { albendazole \& praziquantel }\end{array}$ & No \\
\hline $\begin{array}{l}\text { Larger Case } \\
\quad \text { Series }\end{array}$ & $\begin{array}{l}\text { No. of } \\
\text { Pts }\end{array}$ & \multicolumn{5}{|c|}{ Significant Findings } \\
\hline $\begin{array}{l}\text { Prabhakar et } \\
\text { al., } 2005\end{array}$ & 4 & \multicolumn{5}{|c|}{$\begin{array}{l}4 \text { pts w/ persistent back pain \& paraplegia were found to have spinal hydatid disease. Hematological studies were initially } \\
\text { inconclusive, \& all pts underwent excision after imaging data suggested hydatid disease. } 2 \text { pts required repeat surgery due } \\
\text { to symptomatic recurrence. }\end{array}$} \\
\hline $\begin{array}{l}\text { Hamdan, } \\
2012\end{array}$ & 9 & \multicolumn{5}{|c|}{$\begin{array}{l}9 \text { pts w/ back pain, paraparesis, \& varying degrees of urinary incontinence were found to have spinal hydatid disease. } 8 \text { of } 9 \\
\text { pts had bone involvement, \& the pt w/o bone involvement was shown to have a dumbbell cyst \& recovered fully w/o recur- } \\
\text { rence. The other } 8 \text { required repeat surgery because of neurological deterioration following initial surgery. All pts received } \\
\text { albendazole \& praziquantel. }\end{array}$} \\
\hline
\end{tabular}

Imaging findings may give a hint regarding neuroschistosomiasis. However, further studies must be done before the diagnosis can be confirmed. The presence of ova in the stool or urine or of adult worms in a rectal biopsy specimen is reported in $40 \%$ of acute neuroschistosomiasis cases. ${ }^{9}$ CSF analysis may show eosinophils, lymphocytic pleocytosis, increased protein concentration, and increased IgG index. The most reliable immunological method for diagnosis is the enzyme-linked immunosorbent assay (ELISA), with $50 \%$ sensitivity and $95 \%$ specificity. Indirect hemagglutination assay (IHA) tests have sensitivities ranging from $70 \%$ to $90 \%$, and the combination of both immunological tests has a sensitivity of $90 \%$ and specificity of $93 \% .48$

However, the most definite method of diagnosis is tissue biopsy via surgery. ${ }^{56}$ This is an invasive technique but may be necessary because the presence of schistosomiasis infection on noninvasive tests can be coincidental if the patient lives in an endemic area. A tissue biopsy of a granuloma would show schistosome ova surrounded by necrosis, inflammatory reaction, and demyelination. ${ }^{9}$

There are two pharmaceutical treatment options for spinal cord schistosomiasis: schistosomicidal drugs, such as praziquantel, and steroids.9,48 Praziquantel is the drug of choice for treating schistosomiasis and works directly against adult schistosome worms. ${ }^{18}$ The cure rate associated with this drug is approximately $60 \%$ but can be as high as $85 \%-90 \%$. Steroids work by reducing the inflammatory process that results from ova invasion within the spinal cord. ${ }^{56}$ In addition, surgical removal of granuloma or decompressive laminectomy may also be warranted for symptomatic relief, especially in cases of severe spinal cord compression.

\section{Toxoplasmosis}

Toxoplasmosis is the most common opportunistic CNS infection affecting patients with AIDS. The disease is caused by Toxoplasma gondii, which is an obligate intracellular protozoan parasite. ${ }^{52}$ Approximately 500 million people are infected globally, with the highest incidences being in France and Central America and as high as 17\%$35 \%$ in the US.

The parasite affects two main hosts-cats and humans. It undergoes its sexual cycle within the feline small intestine, and oocysts are then released into water and soil via feces. ${ }^{25}$ Humans are infected after ingesting oocysts through undercooked meats, contact with cats, or contaminated vegetables. Once within the human intestine, oocysts release sporozoites or bradyzoites into the lumen, where they transform and enter into blood and lymphatic 


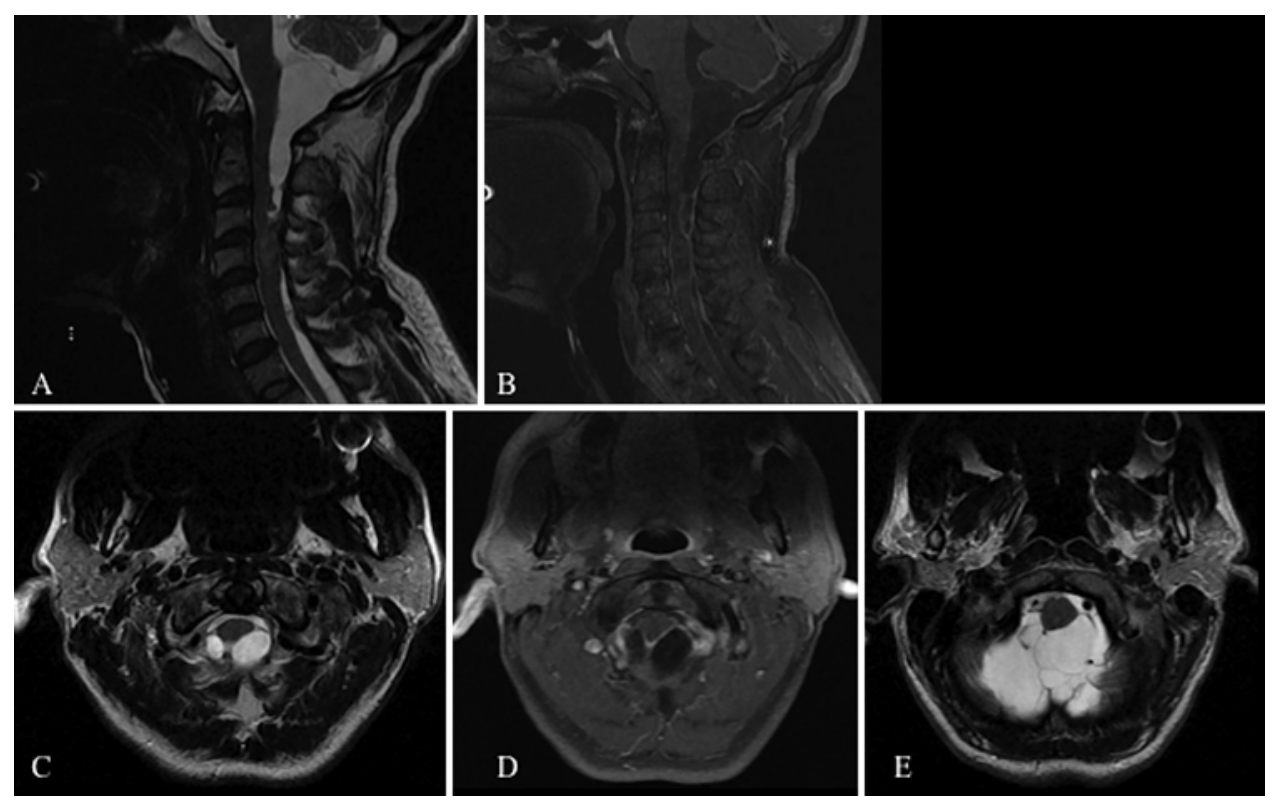

FIG. 1. Case 1. Neurocysticercosis of the cervical spine demonstrated on MRI sequences. A: T2-weighted sagittal image demonstrating cysts in the posterior fossa extending down into the cervical region. B: T1-weighted sagittal image with gadolinium showing the cysts that did not enhance. C: T2-weighted axial image at C1 demonstrating the cystic lesions dorsal to the spinal cord. D: T1-weighted axial image with gadolinium at C1. E: T2-weighted axial image at the base of the posterior fossa.

circulation. They can then reach a number of target sites of infection, one of them being the CNS.

Initial infection can often present with mild lymphadenopathy or may also be asymptomatic. ${ }^{37}$ The infection becomes reactivated in the setting of severe immunosuppression with CD4+ lymphocyte counts less than 200 cells/ $\mathrm{ml}^{2}$-hence its strong association with AIDS. ${ }^{37,47}$ Toxoplasmic encephalitis is a well-studied and -observed syndrome in the setting of immunosuppression. However, spinal cord involvement is not as common a presentation. In addition, infection of the spinal cord is seldom seen alone and is often associated with intracranial involvement. The most common finding in spinal cord toxoplasmosis is vacuolar myelopathy.

García-García et al. found 26 cases of HIV/AIDS-related spinal cord toxoplasmosis in their literature review. ${ }^{25}$ The most common presenting symptoms were extremity weakness, sensory loss, incontinence, and altered deep tendon reflexes. ${ }^{37}$ Although spinal cord toxoplasmosis is not a common presentation, it should be suspected in immunodeficient individuals presenting with acute or subacute myelopathy.

Once again, MRI with contrast is the optimal imaging modality for visualizing infectious lesions. ${ }^{25}$ Lesions will present as hyperintense on T2-weighted or with postcontrast enhancement on T1-weighted sequences. Localized intramedullary ring-enhancing lesions are a common MRI finding associated with toxoplasmosis. ${ }^{26} \mathrm{~A}$ normal spinal cord in the presence of abnormal signal can hint at a vacuolar myelopathy, whereas if there is enlargement of the spinal cord, one should consider Toxoplasma myelitis.

In addition to MRI, CSF cytology and immunological antibody tests are also valuable diagnostic tools. In fact, they are the gold standard for detecting infectious mi-
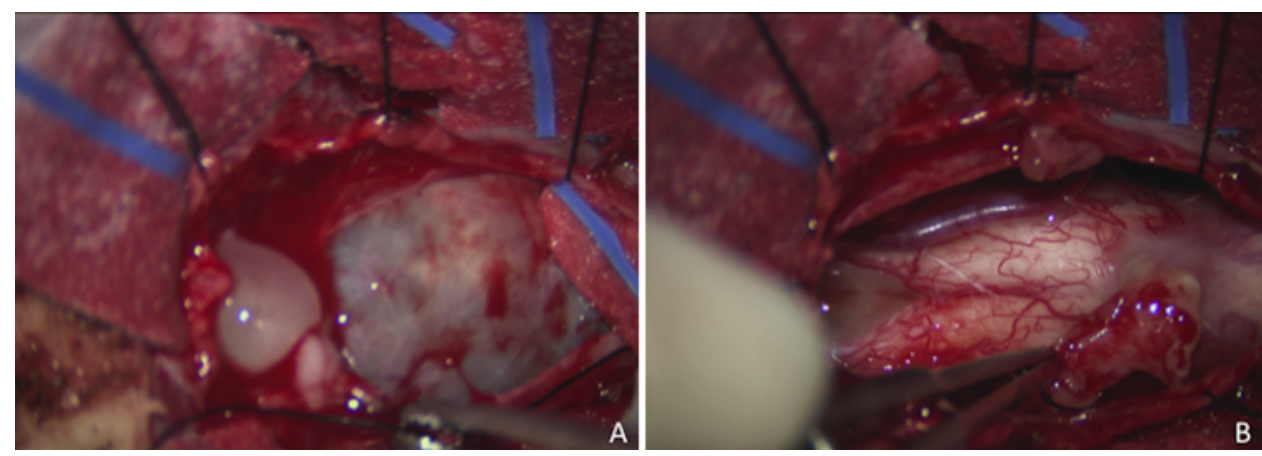

FIG. 2. Case 1. Intraoperative images of a cysticercus, which was identified and subsequently removed via a suboccipital surgical approach. 

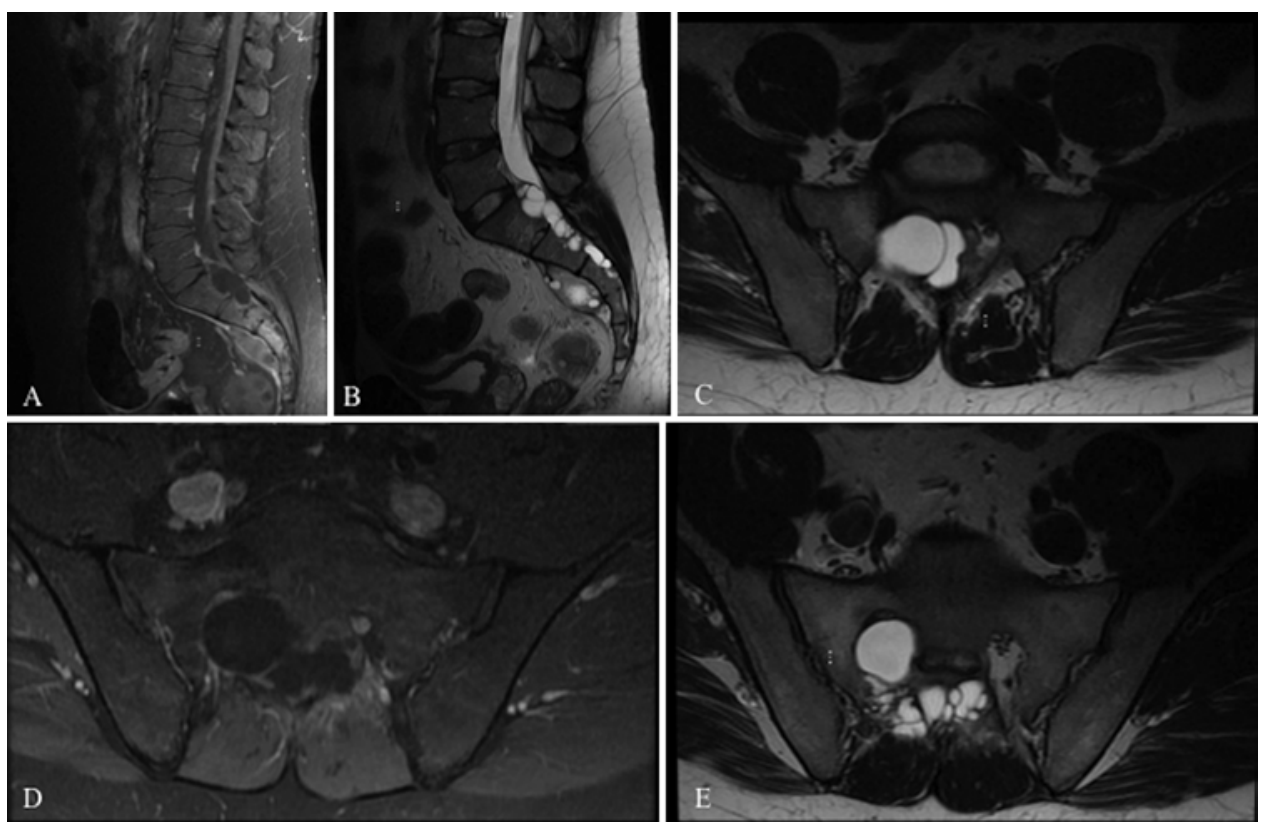

FIG. 3. Case 2. Echinococcosis of the sacral spine demonstrated on MRI sequences. A: T1-weighted sagittal image with gadolinium demonstrating cystic lesions at the sacral region that do not enhance and are isointense when compared to the thecal sac. B: T2-weighted sagittal image demonstrating cysts that extend into the sacral region. C: T2-weighted axial image demonstrating the cystic lesions at $\mathrm{S} 1$ causing mass effect on the thecal sac and traversing roots. D: T1-weighted axial image with gadolinium demonstrating the cysts that did not enhance. E: T2-weighted axial image demonstrating cysts extending into sacral foramina.

croorganisms. ${ }^{26}$ Analysis of CSF can show a moderately elevated protein level up to $1000 \mathrm{mg} / \mathrm{dl}$, normal glucose, and mild mononuclear pleocytosis. ${ }^{25}$ Elevated CSF and serum Toxoplasma IgG and IgM levels can also help with the diagnosis. Tissue biopsy may show the presence of bradyzoites or tachyzoites. However, tissue biopsy has been associated with significant morbidity and mortality, and therefore noninvasive testing is recommended first. ${ }^{3}$ Open spinal cord biopsy should only be performed in the setting of acute decline in function or failure to respond to treatments. ${ }^{46}$

There is not much literature describing a treatment regimen specific to spinal cord toxoplasmosis. Therefore, the same treatment used for toxoplasmic encephalitis is used for spinal cord involvement. ${ }^{3}$ The first-line treatment of choice is a combination of pyrimethamine and sulfadiazine with folinic acid. Trimethoprim-sulfamethoxazole is also an effective therapy option. Steroids have also been used, with success, for treatment of symptoms. ${ }^{25,47}$ There is no well-defined role for surgical intervention in these cases.

\section{Echinococcal Disease}

The two most common causative pathogens of echinococcal disease are Echinococcus granulosus and E. multilocularis. Echinococcus granulosus, also known as the dog tapeworm, is transmitted to humans via the fecal-oral route, usually from the ingestion of eggs found in dog feces. This pathogen usually causes infection in the liver in the form of a hydatid cyst and remains a significant health problem in South America, Eastern Europe, Africa, and western China. ${ }^{32}$ Exposure to sheep is a significant risk factor, and endemic disease tends to occur in places where dogs, the definitive host, might come into frequent contact with sheep, as seen on farms. In such endemic areas, prevalence can be up to $6 \% .{ }^{38}$ Echinococcus multilocularis usually causes alveolar disease and is a significant health concern in Eastern Europe and Central Asia. ${ }^{20}$ The definitive host for E. multilocularis is typically a fox, so infection rates are greatest where there is a high fox population. Although involvement of echinococcal disease in the CNS is rare, the most commonly involved part of the CNS is the thoracic spine. ${ }^{39}$

If spinal involvement is present, the most likely symptoms are nonspecific and are the result of spinal cord compression causing radiculopathy or myelopathy. ${ }^{1}$ However, it is not uncommon for large cysts to remain asymptomatic. It is therefore important for the clinician's differential diagnosis to remain broad when presented with a patient with spinal pathology, because spinal echinococcal disease is potentially curable.

Plain radiographs can visualize cystic lesions in contiguous vertebral bodies, bone lysis, and spondylitis, but follow-up imaging with CT and/or MRI is usually necessary. Ultrasonography may be helpful in detecting abdominal involvement. ${ }^{12} \mathrm{CT}$ provides better bone resolution and can visualize osteolytic lesions in the vertebral bodies. The lesion does not enhance with intravenous contrast. ${ }^{45}$ MRI is the most sensitive imaging modality to detect spinal hydatid disease, but in the absence of MRI, CT myelography can also demonstrate spinal cord involvement. ${ }^{44,45} \mathrm{~T} 1$-weighted images usually demonstrate an isointense or hypointense cyst and cystic wall, whereas T2-weighted images demonstrate a hyperintense cyst with 
a hypointense cystic wall. ${ }^{44}$ Berk et al. describe the lesion on MRI as a unique sausage-like shape with two domeshaped ends with no debris in the lumen. ${ }^{6}$ Last, diffusionweighted imaging can distinguish between spinal hydatid cysts and abscesses because the fluid in abscesses is more viscous, which restricts water movement and yields a hyperintense signal compared to cysts. ${ }^{19}$

The differential diagnosis of spinal echinococcal disease is broad and includes spinal tuberculosis (Mycobacterium tuberculosis and Echinococcus share some endemic areas), malignancy, abscess, and cystic lesions such as spinal arachnoid cysts or spinal aneurysmal bone cysts. ${ }^{17,41}$ Clinical history, imaging studies, and laboratory studies can significantly narrow this differential diagnosis, but only surgical exploration and histopathological examination can provide a definitive diagnosis. Serodiagnostic tests are specific but not sensitive.

Surgery is the treatment of choice for spinal echinococcal disease, although long-term preoperative treatment with an anthelmintic like albendazole may reduce intracystic pressure. ${ }^{27,44}$ The most commonly reported procedure is simple decompression with laminectomy, although the need to perform spinal fusion should always be considered depending on the extent of the lesion. Most of the surgical procedures use a posterior approach, but some studies have reported anterior approaches. ${ }^{44}$ In general, the preference is to remove echinococcal cysts radically because needle aspiration carries a significant risk of cystic rupture. This same principle applies to spinal echinococcal disease, but one case report demonstrated the complete resolution of symptoms in a patient with advanced-stage echinococcosis. ${ }^{54}$ The use of scolicidal agents intraoperatively to prevent the dissemination of the parasite during surgery has been described in abdominal and pelvic cases of hydatid cyst removal.,8 Their use in spinal cases has not been extensively studied but can theoretically provide a similar protective benefit.

\section{Conclusions}

Although parasitic infections of the spine are rare in the developed world, they are worth considering in a differential diagnosis, especially in countries with high rates of immigration and tourism such as the US. Presenting symptoms of parasitic spinal infections are often nonspecific, so their diagnosis can be easily overlooked. Key findings on imaging modalities, laboratory studies suggestive of parasitic infection, and most importantly a thorough patient history are required to correctly diagnose parasitic spinal infections.

\section{References}

1. Abbassioun K, Amirjamshidi A: Diagnosis and management of hydatid cyst of the central nervous system: part 2: hydatid cysts of the skull, orbit, and spine. Neurosurg Q 11:10-16, 2001

2. Adeel AA: Spinal cord schistosomiasis. Sudan J Paediatr 15:23-28, 2015

3. Agrawal SR, Singh V, Ingale S, Jain AP: Toxoplasmosis of spinal cord in acquired immunodeficiency syndrome patient presenting as paraparesis: a rare entity. J Glob Infect Dis 6:178-181, 2014
4. Alsina GA, Johnson JP, McBride DQ, Rhoten PR, Mehringer CM, Stokes JK: Spinal neurocysticercosis. Neurosurg Focus 12(6):e8, 2002

5. Ashraf A, Kirmani AR, Bhat AR, Sarmast AH: A rare case of recurrent primary spinal echinococcosis. Asian J Neurosurg 8:206-208, 2013

6. Berk C, Ciftçi E, Erdoğan A: MRI in primary intraspinal extradural hydatid disease: case report. Neuroradiology 40:390-392, 1998

7. Besim H, Karayalçin K, Hamamci O, Güngör C, Korkmaz A: Scolicidal agents in hydatid cyst surgery. HPB Surg 10:347351, 1998

8. Bhatnagar N, Kishan H, Sura S, Lingaiah P, Jaikumar K: Pelvic hydatid disease: a case report and review of literature. $\mathbf{J}$ Orthop Case Rep 7:25-28, 2017

9. Carod Artal FJ: Cerebral and spinal schistosomiasis. Curr Neurol Neurosci Rep 12:666-674, 2012

10. Chaurasia RN, Mishra VN, Jaiswal S: Spinal cysticercosis: an unusual presentation. BMJ Case Rep 2015:bcr2014207966, 2015

11. Colli BO, Valença MM, Carlotti CG Jr, Machado HR, Assirati JA Jr: Spinal cord cysticercosis: neurosurgical aspects. Neurosurg Focus 12(6): e9, 2002

12. Czermak BV, Unsinn KM, Gotwald T, Niehoff AA, Freund $\mathrm{MC}$, Waldenberger $\mathrm{P}$, et al: Echinococcus granulosus revisited: radiologic patterns seen in pediatric and adult patients. AJR Am J Roentgenol 177:1051-1056, 2001

13. DeGiorgio CM, Medina MT, Durón R, Zee C, Escueta SP: Neurocysticercosis. Epilepsy Curr 4:107-111, 2004

14. Del Brutto $\mathrm{OH}$, Garcia HH: Intramedullary cysticercosis of the spinal cord: a review of patients evaluated with MRI. J Neurol Sci 331:114-117, 2013

15. Del Brutto OH, Nash TE, White AC Jr, Rajshekhar V, Wilkins PP, Singh G, et al: Revised diagnostic criteria for neurocysticercosis. J Neurol Sci 372:202-210, 2017

16. do Amaral LL, Ferreira RM, da Rocha AJ, Ferreira NP: Neurocysticercosis: evaluation with advanced magnetic resonance techniques and atypical forms. Top Magn Reson Imaging 16:127-144, 2005

17. do Amaral LL, Nunes RH, da Rocha AJ: Parasitic and rare spinal infections. Neuroimaging Clin N Am 25:259-279, 2015

18. Doenhoff MJ, Cioli D, Utzinger J: Praziquantel: mechanisms of action, resistance and new derivatives for schistosomiasis. Curr Opin Infect Dis 21:659-667, 2008

19. Doganay S, Kantarci M: Role of conventional and diffusionweighted magnetic resonance imaging of spinal treatment protocol for hydatid disease. J Spinal Cord Med 32:574577, 2009

20. Eckert J, Deplazes P: Biological, epidemiological, and clinical aspects of echinococcosis, a zoonosis of increasing concern. Clin Microbiol Rev 17:107-135, 2004

21. El-On J, Ben-Noun L, Galitza Z, Ohana N: Case report: clinical and serological evaluation of echinococcosis of the spine. Trans R Soc Trop Med Hyg 97:567-569, 2003

22. Ferrari TC, Faria LC, Vilaça TS, Correa CR, Góes AM: Identification and characterization of immune complexes in the cerebrospinal fluid of patients with spinal cord schistosomiasis. J Neuroimmunol 230:188-190, 2011

23. Ferrari TC, Moreira PR: Neuroschistosomiasis: clinical symptoms and pathogenesis. Lancet Neurol 10:853-864, 2011

24. García HH, Evans CAW, Nash TE, Takayanagui OM, White $\mathrm{AC} \mathrm{Jr}$, Botero D, et al: Current consensus guidelines for treatment of neurocysticercosis. Clin Microbiol Rev 15:747-756, 2002

25. García-García C, Castillo-Álvarez F, Azcona-Gutiérrez JM, Herraiz MJ, Ibarra V, Oteo JA: Spinal cord toxoplasmosis in human immunodeficiency virus infection/acquired immunodeficiency syndrome. Infect Dis (Lond) 47:277-282, 2015 
26. Garcia-Gubern C, Fuentes CR, Colon-Rolon L, Masvidal D: Spinal cord toxoplasmosis as an unusual presentation of AIDS: case report and review of the literature. Int J Emerg Med 3:439-442, 2010

27. García-Vicuña R, Carvajal I, Ortiz-García A, López-Robledillo JC, Laffón A, Sabando P: Primary solitary Echinococcosis in cervical spine. Postsurgical successful outcome after long-term albendazole treatment. Spine (Phila Pa 1976) 25:520-523, 2000

28. Gezercan Y, Ökten AI, Çavuş G, Açık V, Bilgin E: Spinal hydatid cyst disease. World Neurosurg 108:407-417, 2017

29. Hamdan TA: Hydatid disease of the spine: a report on nine patients. Int Orthop 36:427-432, 2012

30. Herskowitz A: Spinal cord involvement with Schistosoma mansoni. Case report. J Neurosurg 36:494-498, 1972

31. Hill D, Dubey JP: Toxoplasma gondii: transmission, diagnosis and prevention. Clin Microbiol Infect 8:634-640, 2002

32. Jenkins DJ, Romig T, Thompson RC: Emergence/re-emergence of Echinococcus spp.-a global update. Int J Parasitol 35:1205-1219, 2005

33. Jiang YG, Zhang MM, Xiang J: Spinal cord schistosomiasis japonica: a report of 4 cases. Surg Neurol 69:392-397, 2008

34. Kaen A, Lagares A, Perez-Nuñez A, Rivas JJ, Ramos A, Lobato RD: Intradural extramedullary spinal hydatidosis: case report. Neurocirugia (Astur) 20:282-287, 2009

35. Kamel MH, Murphy M, Kelleher M, Aquilina K, Lim C, Marks C: Schistosomiasis of the spinal cord presenting as progressive myelopathy. Case report. J Neurosurg Spine 3:61-63, 2005

36. Kotil K, Tari R, Savas Y: Medical treatment of primary extradural solitary lumbar hydatid disease. J Clin Neurosci 17:793-795, 2010

37. Kung DH, Hubenthal EA, Kwan JY, Shelburne SA, Goodman JC, Kass JS: Toxoplasmosis myelopathy and myopathy in an AIDS patient: a case of immune reconstitution inflammatory syndrome? Neurologist 17:49-51, 2011

38. Moro P, Schantz PM: Cystic echinococcosis in the Americas. Parasitol Int 55 Suppl:S181-S186, 2006

39. Neumayr A, Tamarozzi F, Goblirsch S, Blum J, Brunetti E: Spinal cystic echinococcosis - a systematic analysis and review of the literature: part 1. Epidemiology and anatomy. PLoS Negl Trop Dis 7:e2450, 2013

40. Neumayr A, Tamarozzi F, Goblirsch S, Blum J, Brunetti E: Spinal cystic echinococcosis - a systematic analysis and review of the literature: part 2. Treatment, follow-up and outcome. PLoS Negl Trop Dis 7:e2458, 2013

41. Nourbakhsh A, Vannemreddy P, Minagar A, Toledo EG, Palacios E, Nanda A: Hydatid disease of the central nervous system: a review of literature with an emphasis on Latin American countries. Neurol Res 32:245-251, 2010

42. Odeku EL, Lucas AO, Richard DR: Intramedullary spinal cord schistosomiasis: case report. J Neurosurg 29:418-423, 1968

43. Palin MS, Mathew R, Towns G: Spinal neuroschistosomiasis. Br J Neurosurg 29:582-584, 2015

44. Pamir MN, Ozduman K, Elmaci I: Spinal hydatid disease. Spinal Cord 40:153-160, 2002

45. Prabhakar MM, Acharya AJ, Modi DR, Jadav B: Spinal hydatid disease: a case series. J Spinal Cord Med 28:426-431, 2005

46. Resnick DK, Comey CH, Welch WC, Martinez AJ, Hoover WW, Jacobs GB: Isolated toxoplasmosis of the thoracic spinal cord in a patient with acquired immunodeficiency syndrome. Case report. J Neurosurg 82:493-496, 1995

47. Rodríguez C, Martínez E, Bolívar G, Sánchez S, Carrascal E: Toxoplasmosis of the spinal cord in an immunocompromised patient: case report and review of the literature. Colomb Med (Cali) 44:232-235, 2013
48. Ross AG, McManus DP, Farrar J, Hunstman RJ, Gray DJ, Li YS: Neuroschistosomiasis. J Neurol 259:22-32, 2012

49. Sah VK, Wang L, Min X, Rizal R, Feng Z, Ke Z, et al: Human schistosomiasis: a diagnostic imaging focused review of a neglected disease. Radiol Infect Dis 2:150-157, 2015

50. Saleem S, Belal AI, El-Ghandour NM: Spinal cord schistosomiasis: MR imaging appearance with surgical and pathologic correlation. AJNR Am J Neuroradiol 26:1646-1654, 2005

51. Sheehan JP, Sheehan J, Lopes MB, Jane JA Sr: Intramedullary spinal cysticercosis. Case report and review of the literature. Neurosurg Focus 12(6):e10, 2002

52. Shih RY, Koeller KK: Bacterial, fungal, and parasitic infections of the central nervous system: radiologic-pathologic correlation and historical perspectives. Radiographics 35:1141-1169, 2015

53. Silva LC, Maciel PE, Ribas JG, Souza-Pereira SR, Antunes CM, Lambertucci JR: Treatment of schistosomal myeloradiculopathy with praziquantel and corticosteroids and evaluation by magnetic resonance imaging: a longitudinal study. Clin Infect Dis 39:1618-1624, 2004

54. Spektor S, Gomori JM, Beni-Adani L, Constantini S: Spinal echinococcal cyst: treatment using computerized tomography-guided needle aspiration and hypertonic saline irrigation. Case report. J Neurosurg 87:464-467, 1997

55. Torabi AM, Quiceno M, Mendelsohn DB, Powell CM: Multilevel intramedullary spinal neurocysticercosis with eosinophilic meningitis. Arch Neurol 61:770-772, 2004

56. Ueki K, Parisi JE, Onofrio BM: Schistosoma mansoni infection involving the spinal cord. Case report. J Neurosurg 82:1065-1067, 1995

57. Wan F, Li L, Chen J, Chen J, Lei T, Xue D, et al: Conus medullaris schistosomiasis. J Neurosurg Spine 5:146-149, 2006

58. White AC Jr, Coyle CM, Rajshekhar V, Singh G, Hauser WA, Mohanty A, et al: Diagnosis and treatment of neurocysticercosis: 2017 clinical practice guidelines by the Infectious Diseases Society of America (IDSA) and the American Society of Tropical Medicine and Hygiene (ASTMH). Clin Infect Dis 66:e49-e75, 2018

59. Zalaquett E, Menias C, Garrido F, Vargas M, Olivares JF, Campos D, et al: Imaging of hydatid disease with a focus on extrahepatic involvement. Radiographics 37:901-923, 2017

60. Zhao JL, Lerner A, Shu Z, Gao XJ, Zee CS: Imaging spectrum of neurocysticercosis. Radiol Infect Dis 1:94-102, 2015

\section{Disclosures}

The authors report no conflict of interest concerning the materials or methods used in this study or the findings specified in this paper.

\section{Author Contributions}

Conception and design: Assina. Acquisition of data: Assina. Analysis and interpretation of data: Assina, Majmundar, Patel, Dodson. Drafting the article: all authors. Critically revising the article: all authors. Reviewed submitted version of manuscript: Assina, Majmundar, Patel, Dodson, Goldstein. Approved the final version of the manuscript on behalf of all authors: Assina. Statistical analysis: Goldstein.

\section{Correspondence}

Rachid Assina: Rutgers New Jersey Medical School, Newark, NJ. assinara@njms.rutgers.edu. 